\title{
Monoclonal Antibodies against Complement 3 Neoantigens for Detection of Immune Complexes and Complement Activation

\author{
Relationship between Immune Complex Levels, State of C3, and Numbers \\ of Receptors for C3b
}

\author{
M. Teresa Aguado, John D. Lambris, George C. Tsokos, Reinhard Burger, Dieter Bitter-Suermann, John D. Tamerius, \\ Frank J. Dixon, and Argyrios N. Theofilopoulos \\ Department of Immunology, Research Institute of Scripps Clinic, La Jolla, California 92037; National Institutes of Health, National \\ Institute of Arthritis, Diabetes, Digestive and Kidney Diseases, Bethesda, Maryland 20205; and Institut fur Immunologie und Serologie, \\ Im Neuenheimer Feld 305, 6900 Heidelberg, Federal Republic of Germany
}

\begin{abstract}
C3-bearing immune complexes and $\mathrm{C} 3$ activation products were detected by using two monoclonal antibodies, one specific for a neoantigenic determinant on $\mathrm{C} 3 \mathrm{c}$ and the other for $\mathrm{C} 3 \mathrm{~d}$. To quantitate immune complexes, the anti-C3c or anti-C3d antibodies were fixed to microtiter plates and reacted with test plasma. The binding of $\mathrm{C} 3$-bearing immune complexes in this plasma was then measured with radioisotope- or enzyme-labeled anti-human IgG. To test for $\mathrm{C} 3$ breakdown products, solid-phase monoclonal antibody to the $\mathrm{C} 3 \mathrm{~d}$ neoantigen was reacted with EDTA-plasma samples, and fixed iC3b or C3d was measured with a polyclonal anti-C3 antibody. Patients with autoimmune diseases, such as systemic lupus erythematosus, rheumatoid arthritis, and Sjogren's syndrome, and paracoccidioidomycosis were found to contain immune complexes bearing $\mathrm{C3b} / \mathrm{iC} 3 \mathrm{~b}$ or $\mathrm{C} 3 \mathrm{~d}$. In most conditions, there were more $\mathrm{C} 3 \mathrm{~d}$-containing immune complexes than $\mathrm{C} 3 \mathrm{~b} / \mathrm{iC} 3 \mathrm{~b}$. Although $\mathrm{CR} 1$ (C3b receptors) rapidly converted immune complex-bound iC3b to $\mathrm{C} 3 \mathrm{dg} / \mathrm{C} 3 \mathrm{~d}$ and lupus patients had reduced CR1, no correlation between the state of $\mathrm{C} 3$ on circulating immune complexes or levels of immune complexes and CR1 numbers was seen. However, levels of C3fixing ICs correlated with levels of $\mathrm{C} 3$ activation products.

This assay system with monoclonal antibodies to neoantigens expressed on activated, but not native, $\mathrm{C} 3$ provides sensitive and specific means for detecting and classifying C3-fixing immune complexes and for assessing $\mathrm{C} 3$ activation.
\end{abstract}

\section{Introduction}

Many assay systems have been devised for immune complex (IC) ${ }^{1}$ detection $(1,2)$. Since most pathogenic ICs activate the

This is publication No. 3725-IMM from the Immunology Department, Research Institute of Scripps Clinic. Dr. Aguado is a recipient of an Arthritis Foundation Postdoctoral Fellowship.

Received for publication 17 December 1984 and in revised form 15 May 1985

1. Abbreviations used in this paper: AHG, aggregated human gammaglobulin; ARG, aggregated rabbit gamma-globulin; BBS, borate-buffered saline; $C$, complement; CR1, complement receptor for C3b; CR2, complement receptor for C3d; CR3, complement receptor for iC3b; HSA, human serum albumin; IC, immune complex; $\mathrm{mAb}$, monoclonal antibody; NHS, normal human serum; PEG, polyethylene glycol; PCM, paracoccidioidomycosis; RA, rheumatoid arthritis; RF, rheumatoid factor; SLE, systemic lupus erythematosus; SS, Sjogren's Syndrome.

\section{J. Clin. Invest.}

(c) The American Society for Clinical Investigation, Inc.

0021-9738/85/10/1418/09 \$1.00

Volume 76, October 1985, 1418-1426 complement (C) system, most of these assays (Clq [3], conglutinin [4], and Raji cell [5]) are based on interactions of certain substances with IC-bound C components. Although these techniques have provided useful information regarding immunopathology, prognosis, and follow-up of immunologic disorders, several drawbacks, particularly lack of specificity, have limited their usefulness.

To improve the specificity of IC assays, we recently described a method based on the interaction of solid phase-bound polyclonal $F\left(a b^{\prime}\right)_{2}$ anti-human $C 3$ and test samples and the subsequent detection of bound C-fixing ICs by labeled anti-IgG or protein A (6). This assay was specific, but competition between IC-bound and free C3 limited its sensitivity. Moreover, since the polyclonal anti- $\mathrm{C} 3$ antibody did not discriminate between $\mathrm{C} 3 \mathrm{~b}$, iC $3 \mathrm{~b}, \mathrm{C} 3 \mathrm{c}$, or $\mathrm{C} 3 \mathrm{dg} / \mathrm{C} 3 \mathrm{~d}, \mathrm{C}$-fixing ICs could not be subcategorized according to the $\mathrm{C} 3$ fragment they bore. Such differentiation may be of value, since cell types that handle or are affected by ICs differ in their expression of the main $\mathrm{C} 3$ receptors (CR1, C3b; CR2, C3d; CR3, iC3b) $(7,8)$. The implication is that the effects of ICs in health and disease may be modified by the C3 fragment they bear. Thus, an estimation of relative amounts of ICs according to their C3 fragment may enhance the prediction of their consequences.

We report here a modification of the solid-phase anti-C3 assay whereby monoclonal antibodies (mAb) recognizing neoantigenic determinants on $\mathrm{C} 3 \mathrm{c}$ or $\mathrm{C} 3 \mathrm{~d}$, instead of polyclonal anti-C3 antibodies, have been used as substrates. This modification achieves three goals: $(a)$ the assay shows exquisite specificity and sensitivity; $(b)$ C3-fixng ICs in patient plasmas can be characterized with regard to the $\mathrm{C} 3$ fragment they express; and (c) simultaneous with IC detection, levels of $\mathrm{C} 3$ activation products can be ascertained by replacing the final anti-Ig reagent used for IC estimation with a polyclonal anti-C3 antibody.

\section{Methods}

Proteins. C fragments $\mathrm{C} 3 \mathrm{~b}, \mathrm{iC} 3 \mathrm{~b}, \mathrm{C} 3 \mathrm{c}$, and $\mathrm{C} 3 \mathrm{~d}$ were either supplied to us by Dr. M. K. Pangburn (Scripps Clinic and Research Foundation) (9) or prepared as described (10). Human serum albumin (HSA) was purchased from Miles Laboratories (Elkhart, IN), and bovine serum albumin (BSA) from Calbiochem-Behring Corp. (La Jolla, CA). Human IgG was purchased from Sigma Chemical Co. (St. Louis, MO), and further purified by ion exchange chromatography in a DE-52 column. Mouse, rat, and rabbit $\mathrm{IgG}$ were obtained from Miles Laboratories. Cohn Fraction II, inulin, and zymosan were purchased from Sigma Chemical Co.

Antibodies. Six mAb and one polyclonal anti-C3 antibody were used. Three of the available monoclonals, mAb-105 (11), mAb-4 (12), mAbBRL (purchased from Bethesda Research Laboratories, Gaithersburg, $\mathrm{MD}$ ) were against antigenic determinants on the $\mathrm{C} 3 \mathrm{c}$ fragment; the other three, mAb-130 (13), mAb-3 (12), and mAb-ORTHO (Ortho Diagnostics, 
Raritan, NJ) were against C3d. Two antibodies, mAb-3 and mAb-4, originated from rat, and the remainder from mouse. Animals were immunized with human $\mathrm{C} 3$ or fragments thereof, except for $\mathrm{mAb}-105$, which was raised against guinea pig $\mathrm{C} 3$ but was shown to cross-react with human $\mathrm{C} 3$ (11). mAb-105 and $\mathrm{mAb}-\mathrm{BRL}$ were used directly in the form of ascites fluids, whereas all others were used as IgG fractions after ammonium sulfate precipitation of ascites fluids and subsequent IgG purification on DE-52 columns or protein A-Sepharose columns. The IgG and its $\mathrm{F}\left(\mathrm{ab}^{\prime}\right)_{2}$ fraction of the polyclonal IgG goat anti-human $\mathrm{C} 3$ antibody were prepared as described previously (6).

Other antibodies were the following: (a) rabbit anti-human IgG prepared by affinity purification on human IgG-Sepharose columns; $(b)$ peroxidase-conjugated sheep anti-human IgG, obtained from Cappel Laboratories (Cochranville, PA); (c) goat anti-rabbit IgG purchased from Miles Laboratories; $(d)$ rabbit anti-BSA isolated by affinity chromatography on a BSA-Sepharose column and rendered aggregate-free by passage through a Sephadex G-200 column; $(e)$ polyclonal anti-C3b receptor (anti-CR1) antibody from rabbits immunized with human CR1 as described (14); and ( $f$ ) peroxidase-conjugated goat anti-mouse IgG obtained from Cappel Laboratories. The above antisera were used as whole IgG or as $F\left(a b^{\prime}\right)_{2}$ fragments prepared by pepsin digestion (15).

In vitro models of ICs. Aggregated human gamma-globulin (AHG) was prepared by heating of Cohn Fraction II in phosphate-buffered saline (PBS), $\mathrm{pH} 7.5$, at $63^{\circ} \mathrm{C}$ for $30 \mathrm{~min}$. Large aggregates were removed by centrifugation at $3,000 \mathrm{rpm}$ for $15 \mathrm{~min}$, and aliquots were stored at $-70^{\circ} \mathrm{C}$. Aggregated rabbit IgG (ARG) was similarly made, with heating at $72^{\circ} \mathrm{C}$ for $20 \mathrm{~min}$. Soluble BSA-anti-BSA complexes were prepared at five times antigen excess (16)

Radioiodination. ${ }^{125}$ I antibody labeling was performed by the chloramine $\mathrm{T}$ method (17), whereas $\mathrm{C} 3$ fragments were labeled with the iodogen method (18).

Test samples. Venous blood was collected in EDTA $(0.01 \mathrm{M}$ final concentration). Plasma samples from normal individuals $(n=18)$ and patients with systemic lupus erythematosus (SLE, $n=120$ ), rheumatoid arthritis (RA, $n=92$ ), Sjogren's syndrome (SS, $n=28$ ), and paracoccidioidomycosis (PCM, $n=31$ ) at various stages of disease activity were analyzed. Plasma aliquots were stored at $-70^{\circ} \mathrm{C}$ and thawed once. DNA binding capacity and $\mathrm{CH} 50$ levels in serial studies with SLE patients were provided by Dr. R. G. Lahita, The Rockefeller University, New York.

Binding of $C 3$ fragments to anti-C3 antibodies. The test was carried out in two systems: (a) Microtiter wells were coated with C3 fragments, free sites blocked with $1 \%$ HSA-borate-buffered saline (BBS), and serial dilutions of the mAbs were allowed to react for $30 \mathrm{~min}$ at room temperature. Plates were washed three times and peroxidase-conjugated goat anti-mouse IgG was added. After 30 -min incubation at $37^{\circ} \mathrm{C}$ and color development, plates were read at $412 \mathrm{~nm}$ in a Dynatech MR600. (b) Microtiter wells were coated with $\mathrm{mAbs}$, nonreacting sites were blocked with $1 \%$ HSA-BBS, pH 7.5, and serial dilutions of radiolabeled $\mathrm{C} 3$ fragments were added. After 2-h incubation at $37^{\circ} \mathrm{C}$, plates were washed five times, and wells cut and counted.

IC assay. The assay is a modification of that described by Pereira et al. (6). Flexible microtiter plates with U-shaped wells (Dynatech Laboratories, Inc., Alexandria, VA) were coated with $50 \mu \mathrm{l}$ of an appropriate dilution of anti-C3 antibodies (see Results) in BBS, pH 7.5, and incubated at $4^{\circ} \mathrm{C}$ overnight. The material was then aspirated, and $150 \mu \mathrm{l}$ of $1 \%$ HSA-BBS was added to each well to cover unreacted sites. After $1 \mathrm{~h}$ at room temperature, wells were washed once with BBS. Then, $50 \mu \mathrm{l}$ of test plasma diluted $1: 21$ in BBS that contained $1 \%$ HSA, $0.2 \%$ Tween 20, $0.01 \mathrm{M}$ EDTA, and $0.1 \%$ aggregated mouse or rat IgG (depending on the mAb origin) was added in duplicate wells. Excess heterologous IgGs were added to avoid false positive results caused by rheumatoid factors (RFs). Simultaneously, as a standard, various amounts of AHG (3.12 to $800 \mu \mathrm{g} / \mathrm{ml}$ ) were incubated for $15 \mathrm{~min}$ at $37^{\circ} \mathrm{C}$ with normal human serum (NHS) to fix C, diluted as above, and added to antibodycoated wells. After $2 \mathrm{~h}$ at $37^{\circ} \mathrm{C}$, the wells were washed three times with $0.2 \%$ Tween $20-\mathrm{BBS}$, and $50 \mu \mathrm{l}(200 \mathrm{ng})$ radioiodinated $\mathrm{F}\left(\mathrm{ab}^{\prime}\right)_{2}$ rabbit anti-human IgG was added. After further incubation for $2 \mathrm{~h}$ at $37^{\circ} \mathrm{C}$, the plates were washed three times and cut out wells counted. The uptake of radioiodinated anti-human IgG bound per well was calculated from the specific activity of the labeled antibody.

Data were analyzed by the least square method from standard curves using the nanograms of anti-human IgG bound and the micrograms of added AHG ( $\log _{2}$ concentration). Linear, logarithmic, exponential, and polynomical curves were tested to identify the best fit. A logarithmic transformation of the nanograms of anti-IgG bound proved optimal, based on an analysis of variances and the $F$ distribution. The IC level results were expressed as microgram equivalent $\mathrm{AHG} / \mathrm{ml}$. When enzyme immunoassay was used, peroxidase-conjugated anti-human IgG was employed as final reagent. For comparison, the Raji cell assay was also performed in some samples, as described previously (5).

Detection of $C 3$ activation products. Microtiter wells were coated with $\mathrm{mAb}-130$ as described above. This $\mathrm{mAb}$ reacts only with activated, not native $\mathrm{C} 3$, and binds $\mathrm{iC} 3 \mathrm{~b}$ and $\mathrm{C} 3 \mathrm{~d}$ fragments either fixed to substrates or free in solution (see Results). Plasmas to be tested for $\mathrm{C} 3$ activation were diluted 1:50 in BBS that contained 1\% HSA, 0.2\% Tween 20, 0.01 $M$ EDTA, and $50 \mu \mathrm{l}$ was added to the wells. After $45 \mathrm{~min}$ at $4^{\circ} \mathrm{C}$, samples were aspirated and wells were washed three times with $0.2 \%$ Tween 20 BBS. Thereafter, $50 \mu \mathrm{l}(1 \mu \mathrm{g})$ of ${ }^{125}$ I-labeled polyclonal $\mathrm{F}\left(\mathrm{ab}^{\prime}\right)_{2}$ anti-human $\mathrm{C} 3$ was added, incubation was carried out for $1 \mathrm{~h}$ at $37^{\circ} \mathrm{C}$, and, after three washes, wells were cut out and counted. Controls included normal plasmas and $\mathrm{NHS}$ treated $\left(37^{\circ} \mathrm{C}, 30 \mathrm{~min}\right)$ with various $\mathrm{C}$ system activators (inulin, $20 \mathrm{mg} / \mathrm{ml}$; zymosan, $5 \mathrm{mg} / \mathrm{ml}$; AHG, $1,600 \mu \mathrm{g} / \mathrm{ml}$ serum). Before testing, inulin and zymosan were removed by centrifugation (10 $\mathrm{min}$ at $3,000 \mathrm{rpm}$ ). AHG were removed in some instances by precipitation with polyethylene glycol (PEG [ $3 \%$ final concentration]).

Measurement of $C R I$ receptors on erythrocytes. Erythrocytes from venous blood of normal individuals $(n=12)$ and IC-positive SLE $(n=32)$ patients that had been anti-coagulated in 0.01 M EDTA and held at $4^{\circ} \mathrm{C}$ were washed three times with PBS containing $0.1 \%$ rabbit IgG and counted in a Coulter counter. Erythrocytes $\left(3.3 \times 10^{6}\right.$ in $0.1 \%$ rabbit IgG-PBS) were incubated for $45 \mathrm{~min}$ at $20^{\circ} \mathrm{C}$ with $1 \mu \mathrm{g}{ }^{125} \mathrm{I}$-labeled $\mathrm{F}\left(\mathrm{ab}^{\prime}\right)_{2}$ anti-CR 1 or, as control, radiolabeled $\mathrm{F}\left(\mathrm{ab}^{\prime}\right)_{2}$ anti-BSA. This amount of anti-CRI antibody was found to exceed that required for CRI receptor saturation in several normal persons and patients. Duplicate cell samples in $0.1 \mathrm{ml}$ were removed from each mixture, layered on 0.3 $\mathrm{ml}$ of $20 \%$ sucrose in PBS in polyethylene microfuge tubes (VWR Scientific, Inc., Gibbstown, NJ), and pelleted by centrifugation at $8,000 \mathrm{~g}$ for $5 \mathrm{~min}$. Tube tips were cut and the pellets counted. The counts per minute obtained with anti-BSA were subtracted, and the results expressed as specific counts of anti-CR1 antibody bound to cells. The data were

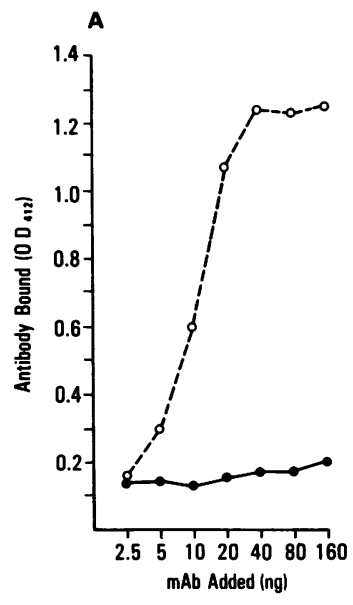

B

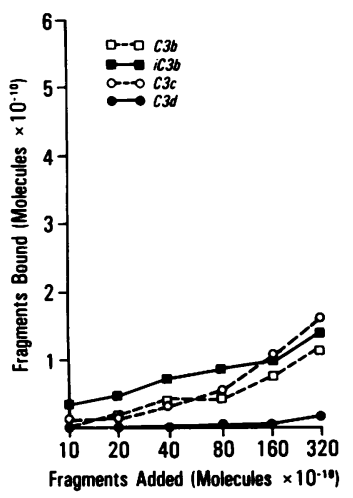

Figure 1. Specificity of mAb-105 for $\mathrm{C} 3$ fragments. $(A)$ Microtiter wells were coated with $\mathrm{C} 3 \mathrm{c}$ or $\mathrm{C} 3 \mathrm{~d}$, reacted with $\mathrm{mAb}-105$, and finally incubated with peroxidase-conjugated anti-mouse IgG. $(B)$ Alternatively, wells were coated with $\mathrm{mAb}-105$ and reacted with radiolabeled $\mathrm{C} 3 \mathrm{~b}, \mathrm{iC} 3 \mathrm{~b}, \mathrm{C} 3 \mathrm{c}$, and C3d. 


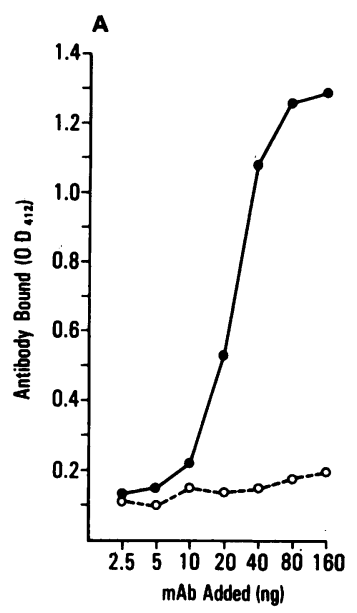

B

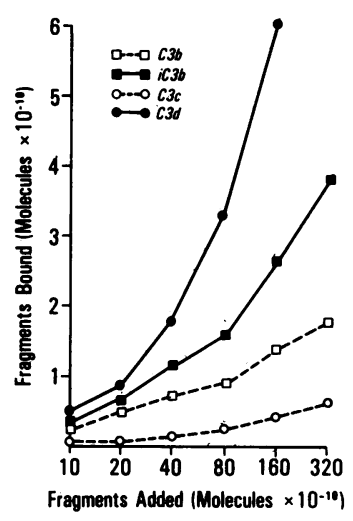

Figure 2. Specificity of $\mathrm{mAb}-130$ for $\mathrm{C} 3$ fragments. $(A)$ Microtiter wells were coated with $C 3 c$ or $C 3 d$, reacted with $\mathrm{mAb}-130$, and finally incubated with peroxidase-conjugated anti-mouse IgG. $(B)$ Alternatively, wells were coated with mAb-130 and reacted with radiolabeled $\mathrm{C} 3 \mathrm{~b}, \mathrm{iC} 3 \mathrm{~b}, \mathrm{C} 3 \mathrm{c}$, and C3d.

then transformed to numbers of CR 1 antigenic sites per cell as described by Wilson et al. (19), using a standard curve derived from bindings of incremental amounts of ${ }^{125} \mathrm{I}$-dimeric $\mathrm{C} 3 \mathrm{~b}$ and ${ }^{125} \mathrm{I} F\left(\mathrm{ab}^{\prime}\right)_{2}$ anti-CR 1 antibody on similar numbers of normal erythrocytes.

Statistical methods. The Spearman rank correlation coefficient was used in all statistical analyses.

\section{Results}

Specificities of $m A$ bs to $C 3$. The C3 fragment specificities of some of the mAbs in this study have been defined, primarily by agglutination or binding to antibody and/or C-sensitized particles (11-13). Verification of these specificities in our solid-phase assay systems was sought. As depicted in Fig. $1 A$, when $\mathrm{C} 3$ fragments bound in microtiter wells, mAb-105 reacted with $\mathrm{C} 3 \mathrm{c}$, but not $\mathrm{C} 3 \mathrm{~d}$. Conversely, when mAb-105 was added to microtiter wells before assessment of radiolabeled soluble $\mathrm{C} 3 \mathrm{~b}, \mathrm{iC} 3 \mathrm{~b}, \mathrm{C} 3 \mathrm{c}$, or C3d uptake, weak binding with the first three fragments, but no binding with $\mathrm{C} 3 \mathrm{~d}$, followed (Fig. $1 B$ ). In contrast, mAb-130 interacted with $\mathrm{C} 3 \mathrm{~d}$, but not $\mathrm{C} 3 \mathrm{c}$; binding of $\mathrm{C} 3 \mathrm{~d}$ to $\mathrm{mAb}-130$ was independent of whether this fragment was offered on a solid matrix or in fluid phase (Fig. 2, $A$ and $B$ ). Binding of fluid phase $\mathrm{iC} 3 \mathrm{~b}$ to $\mathrm{mAb}-130$ was almost as strong as that of $\mathrm{C} 3 \mathrm{~d}$, whereas binding of fluid phase $\mathrm{C} 3 \mathrm{~b}$ was weak (Fig. $2 \mathrm{~B}$ ). When mAbs were first bound in the wells before incubation with radiolabeled fragments, $m A b-4$ and $m A b-B R L$ reacted with $C 3 b$; $i C 3 b$, and $\mathrm{C} 3 \mathrm{c}$, but not $\mathrm{C} 3 \mathrm{~d}$, whereas $\mathrm{mAb}-3$ and $\mathrm{mAb}-\mathrm{ORTHO}$ reacted with $\mathrm{C} 3 \mathrm{~b}$, iC3b, and $\mathrm{C} 3 \mathrm{~d}$, but not $\mathrm{C} 3 \mathrm{c}$ (data not shown).

$m A b s$ reactive with $C 3$ neoantigenic determinants. By using sensitized erythrocytes, Tamerius et al. (13) observed that mAb130 recognized determinants expressed on activated, but not native, C3. We devised a solid-phase assay system to determine which of the mAbs could discriminate between activated and native C3. Microtiter wells were coated with each of the mAbs and reacted with EDTA-plasma or serum to which $C$ activators (AHG, inulin, and zymosan) had been added; bound $\mathrm{C} 3$ was then detected with a radiolabeled polyclonal anti-C3 antibody. As shown in Table I, among the anti-C3c mAbs, only mAb-105 clearly discriminated activated from nonactivated $\mathrm{C} 3$, i.e., 53 ng of anti-C3 bound to mAb-105 coated wells incubated with serum + AHG, but only $7 \mathrm{ng}$ in EDTA-plasma. Similarly, among the anti-C3d mAbs, only mAb-130 substantially differentiated activated from native $\mathrm{C} 3$ (72 vs. $11 \mathrm{ng}$ anti-C3 uptake, respectively). Of considerable interest, the amount of $\mathrm{C} 3$ (as assessed by uptake of polyclonal anti-C3) bound to $\mathrm{mAb}-105$ was markedly reduced if the activator AHG had been removed by $3 \%$ PEG before testing. Furthermore, $\mathrm{C} 3$ binding to $\mathrm{mAb}-105$ was low when particulate activators such as inulin and zymosan had been removed by centrifugation before assaying. In contrast, mAb-130 bound almost equal amounts of $C 3$ whether the activating principle (AHG, zymosan, or inulin) was present in the incubation or had been removed. Therefore, mAb-105 preferentially recognizes an activator- or surface-bound neoantigenic determinant on $\mathrm{C} 3 \mathrm{c}$, whereas $\mathrm{mAb}-130$ reacts equally well with activator- or surface-bound and free in fluid phase neoantigenic determinant on C3d.

Modified anti-C3 assay for IC detection. We next modified the solid-phase anti-C3 IC assay (6) by substituting the polyclonal anti-C3 antibody for one of the two mAbs reactive with neoantigenic determinants on $\mathrm{C} 3 \mathrm{c}$ or $\mathrm{C} 3 \mathrm{~d}$. Bound $\mathrm{IgG}$ was detected with radiolabeled or enzyme-conjugated anti-IgG. Fig. 3 shows sensitivity curves in detecting model ICs (AHG) in human serum with $\mathrm{mAb}-105$ or $\mathrm{mAb}-130$, and a polyclonal antibody for comparison. Both $\mathrm{mAbs}$ detected as little as $6.25 \mu \mathrm{g} \mathrm{AHG} / \mathrm{ml}$ serum. The polyclonal IgG anti-C3 antibody showed much lower sensitivity, with uptake higher than that in serum alone only when AHG exceeded $50 \mu \mathrm{g} / \mathrm{ml}$.

Absence of non-IC-derived low molecular weight C3-bearing IgG in serum samples with added ICs. It has been reported that generation of nascent $\mathrm{C} 3 \mathrm{~b}$ by ICs in serum results in a bystander

Table I. Ability of Monoclonal Anti-C3 Antibodies to Discriminate between Native and Activated C3

\begin{tabular}{|c|c|c|c|c|c|c|}
\hline \multirow[b]{2}{*}{ Samples added* } & \multicolumn{3}{|c|}{ Monoclonal Anti-C3c Antibodies } & \multicolumn{3}{|c|}{ Monoclonal Anti-C3d Antibodies } \\
\hline & $\mathrm{mAb}-4$ & $\mathrm{mAb}-105$ & mAb-BRL & $\mathrm{mAb}-3$ & $\mathrm{mAb}-130$ & mAb-ORTHO \\
\hline Serum + EDTA & $25^{\prime \prime}$ & 7 & 83 & 23 & 11 & 28 \\
\hline Serum + AHG & 49 & 53 & 90 & 35 & 72 & 43 \\
\hline Serum + AHG + PEG & 32 & 19 & 84 & 25 & 58 & 26 \\
\hline Serum + inulin $\S$ & 26 & 16 & 87 & 20 & 63 & 24 \\
\hline Serum + zymosan $\S$ & 30 & 17 & 75 & 19 & 57 & 22 \\
\hline
\end{tabular}

* Serum was activated with AHG $(1,600 \mu \mathrm{g} / \mathrm{ml})$, inulin $(20 \mathrm{mg} / \mathrm{ml})$, or zymosan $(5 \mathrm{mg} / \mathrm{ml})$. $¥$ AHG was removed with $3 \%$ PEG before testing. $\S$ Inulin and zymosan were removed by centrifugation. "Numbers represent mean values of three experiments with three different normal sera. Results are expressed as nanograms of polyclonal anti-C 3 bound per well. 


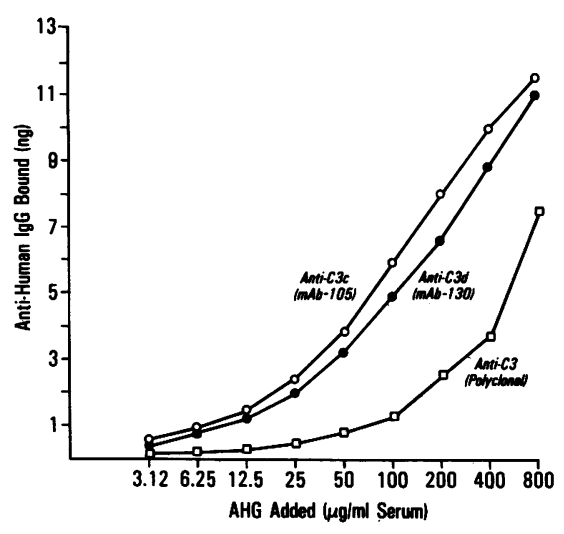

Figure 3. Detection of C-fixing ICs by a solid-phase assay using antiC3 antibodies. Microtiter wells were coated with monoclonal or polyclonal anti-C3 antibodies, reacted with serum that contained increasing amounts of AHG as model of ICs, and finally incubated with radiolabeled anti-human IgG. Nanograms of bound anti-IgG were measured.

binding or metastasis of IC-fixed C3b to monomeric IgG (20). If so, the anti-C3 assay may give false positive results and/or inaccurate estimation of true serum IC levels. To address this issue, we coated microtiter wells with mAb-105 (anti-C3c) or $\mathrm{mAb}-130$ (anti-C3d) and reacted them with a mixture containing NHS as a $\mathrm{C}$ source and ICs made with rabbit antibodies (BSArabbit anti-BSA or ARG). Bound rabbit IgG in the form of complex or human IgG present in monomeric form in the $\mathrm{C}$ source were detected with radiolabeled anti-rabbit IgG and anti-human IgG, respectively. As shown in Table II, mAb-105 or mAb-130 coated wells incubated with human serum to which ICs containing rabbit antibody had been added reacted only with antirabbit, but not anti-human, IgG. Wells incubated with human serum containing AHG registered binding with anti-human IgG, as expected. Therefore, under the conditions of our experiment, we did not observe significant metastatic or bystander binding of IC-generated C3 fragments to monomeric IgG.

Kinetics of C3 fragments' retention by ICs in mixtures with serum or serum $+C R I$. AHG in serum have been reported to

Table II. Absence of C3 on Monomeric IgG after C3 Activation by ICs

\begin{tabular}{clll}
\hline $\begin{array}{l}\text { Primary coating } \\
\text { antibody }\end{array}$ & $\begin{array}{l}\text { Materials added to human } \\
\text { serum (C source)* }\end{array}$ & $\begin{array}{l}\text { Anti-rabbit } \\
\text { IgG }\end{array}$ & $\begin{array}{l}\text { Anti-human } \\
\text { IgG }\end{array}$ \\
\hline & & ng bound & ng bound \\
mAb-105 & & & \\
(anti-C3c) & ARG & $12.78 \ddagger$ & 0.36 \\
& BSA-rabbit-anti-BSA & 47.87 & 0.79 \\
& AHG & 0.53 & 14.78 \\
mAb-130 & ARG & 9.37 & 0.23 \\
(anti-C3d) & BSA-rabbit-anti-BSA & 50.03 & 0.47 \\
& AHG & 0.41 & 13.56 \\
\hline
\end{tabular}

* Serum was incubated (60 min) with BSA-rabbit-anti-BSA, ARG, or AHG at a final concentration of $1,600 \mu \mathrm{g} / \mathrm{ml}$. Increasing the incubation period to $24 \mathrm{~h}$ did not modify the results.

$¥$ Numbers represent mean values of three experiments with three different normal sera. retain C3 fragments and reactivity with anti-C3 polyclonal antibodies for only $\sim 60 \mathrm{~min}(20)$. Recently, Medoff and co-workers $(21,22)$ and Ross et al. (23) demonstrated that cell surface CR1 (the bulk of which is represented on the large numbers of erythrocytes) participate as co-factors with factor I, and perhaps factor $\mathrm{H}$, of the $\mathrm{C}$ system in rapidly degrading IC-bound $\mathrm{C} 3 \mathrm{~b}$ to $\mathrm{iC} 3 \mathrm{~b}$ and finally to $\mathrm{C} 3 \mathrm{dg} / \mathrm{C} 3 \mathrm{~d}$. We tested whether model ICs (AHG and BSA-anti-BSA) incubated for various times with human serum alone or with erythrocytes (a more physiologic combination) $(a)$ retained $m A b$ reactivity, $(b)$ registered different values with anti-C3c or anti-C3d mAbs, and $(c)$ had values affected by the numbers of $C R 1$ in the mixture? A representative experiment of this type with erythrocytes from two individuals, of which one had high CRI phenotype (736 CR1/erythrocyte) and the other low CR1 (140 CR1/erythrocyte) is shown in Fig. 4. Similar results were found in four other individuals, two with low CR1 numbers and two with high CR1 numbers. As illustrated in Fig. $4 \mathrm{~A}$, the amount of anti-human IgG (reflecting the quantity of C-fixing AHG bound) reacting with $\mathrm{mAb}-105$ (anti-C3c) coated wells decreased substantially when the aggregates were left for long periods in serum ( $50 \%$ reduction by $24 \mathrm{~h}$ ). Reductions were similar when erythrocytes with low CR 1 receptors were added to the AHG and serum mixture. However, if erythrocytes with high numbers of CR1 receptors were included, the AHG level reduction registered with the anti-C $3 \mathrm{c}$ mAb-105 was greatly expedited (Fig. $4 A, 50 \%$ reduction by $3-4 \mathrm{~h}$ ). In contrast, the levels of AHG detected with the anti-C3d mAb-130 decreased

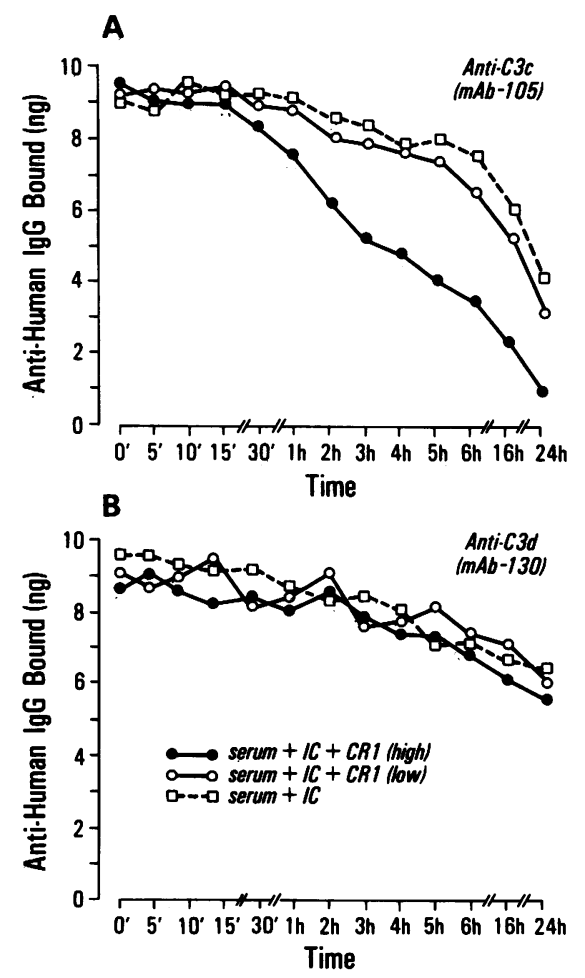

Figure 4. Effect of membrane-associated CR1 (erythrocytes) on the state of IC-bound C 3 fragment. AHG $(400 \mu \mathrm{g} / \mathrm{ml})$ was incubated with fresh NHS for $15 \mathrm{~min}$ at $37^{\circ} \mathrm{C}$ before testing. Subsequently, sera containing AHG or AHG and CR1 $\left(4.5 \times 10^{9} \mathrm{cells} / \mathrm{ml}\right.$; high number, 736 CR 1/erythrocyte; low number, $140 \mathrm{CR} 1 /$ erythrocyte) were incubated for different periods at $37^{\circ} \mathrm{C}$. $\mathrm{C} 3 \mathrm{~b} / \mathrm{iC} 3 \mathrm{~b}$-containing complexes were measured with $\mathrm{mAb}-105$ (anti-C3c, $A$ ), whereas iC $3 \mathrm{~b} / \mathrm{C} 3 \mathrm{~d}$-containing complexes were measured with $\mathrm{mAb}-130$ (anti-C3d, $B$ ). 


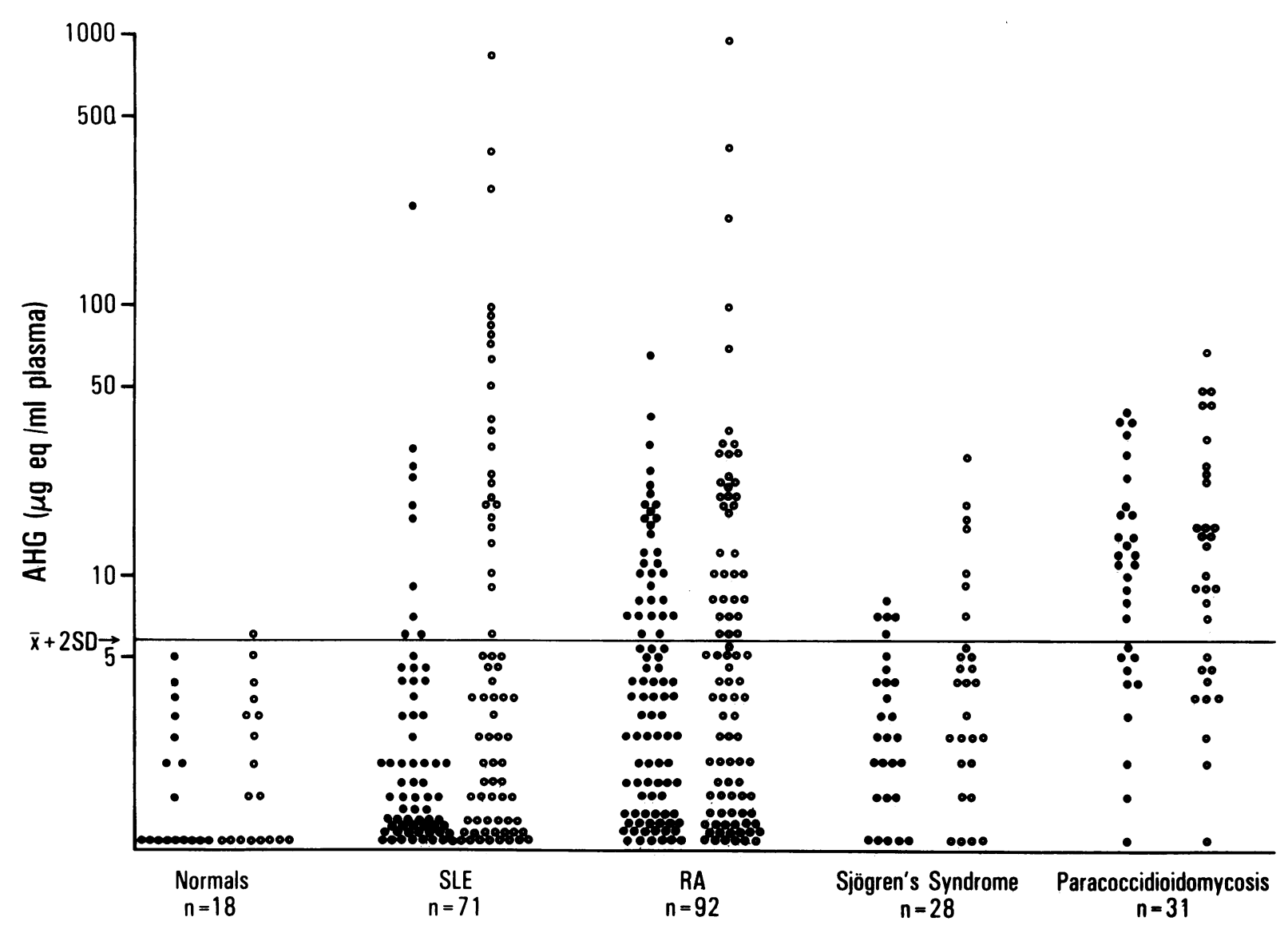

Figure 5. Levels of $\mathrm{C} 3 \mathrm{~b} / \mathrm{iC} 3 \mathrm{~b}-(\bullet)$ and $\mathrm{iC} 3 \mathrm{~b} / \mathrm{C} 3 \mathrm{~d}-(\bullet)$ containing ICs in pathologic plasmas.

slightly with time (Fig. $4 \mathrm{~B}, \sim 20-30 \%$ over a 24 -h period), and, as expected, were not influenced by the presence and/or numbers of $C R 1$, since $\mathrm{mAb} 130$ reacts with $\mathrm{iC} 3 \mathrm{~b}$ and $\mathrm{C} 3 \mathrm{~d}$. This slight to moderate reduction might be caused by release of some $\mathrm{C} 3 \mathrm{~d}$ from the complex, as described by Law et al. (24). Results were similar when BSA-rabbit-anti-BSA ICs were used instead of AHG, i.e., a 50\% reduction occurred after $2 \mathrm{~h}$ with the anti-C3c antibody, but only a 20-30\% after $24 \mathrm{~h}$ with the anti-C3d antibody (data not shown). These results indicate that mAb-130 reacting with $\mathrm{iC} 3 \mathrm{~b}$ as well as the end product of $\mathrm{C} 3$ degradation (C3dg/C3d) detects most of the C3-bearing ICs independently of the duration of exposure to $\mathrm{C} 3 \mathrm{~b} / \mathrm{iC} 3 \mathrm{~b}$-converting factors.

Detection of ICs in human plasma. 18 plasmas from healthy volunteers were analyzed using $\mathrm{mAb}-130$ (anti-C3d) and $\mathrm{mAb}$ 105 (anti-C3c), giving a mean value \pm 2 SD of $2.36 \pm 4.08 \mu \mathrm{g}$ of AHG eq/ml and $2.01 \pm 4.78 \mu \mathrm{g}$ of AHG eq $/ \mathrm{ml}$. High levels $(>2$ SD of normal) of IC were detected with both monoclonal antibodies in several patients with autoimmune syndromes or a parasitic disease (Fig. 5). A good correlation was found between values obtained with anti-C3d and anti-C3c monoclonal antibodies in each group of patients with the following correlation coefficients: SLE $(r=0.66)$, RA $(r=0.73)$, SS $(r=0.54)$, and PCM $(r=0.75)$, with $P<0.01$ in all cases.

To determine whether the IC expressed predominantly $\mathrm{C} 3 \mathrm{dg} /$ $\mathrm{C} 3 \mathrm{~d}$ or $\mathrm{C} 3 \mathrm{~b} / \mathrm{iC} 3 \mathrm{~b}$, the IC-positive plasmas were compared. A large proportion of patients with autoimmune diseases (SLE, RA, and SS) registered higher values in the sample with anti$\mathrm{C} 3 \mathrm{~d}$ than anti-C3c mAb as substrate, whereas most of the PCM patients registered equivalent values with both antibodies (Fig. 6). Serial studies were performed on five SLE patients. In Fig.
7 , the results of the different parameters studied on one of them are shown. Exacerbation of the individual's disease, corresponding to increased anti-DNA antibodies and decreased complement levels, correlated, in general, with increases in the levels of IC. Finally, the results obtained with mAb-130 in RA and SLE patients were compared with IC levels registered by the Raji cell assay. In RA patients, a good correlation between these two assays was noted $(r=0.61, P<0.01)$. However, in SLE patients,

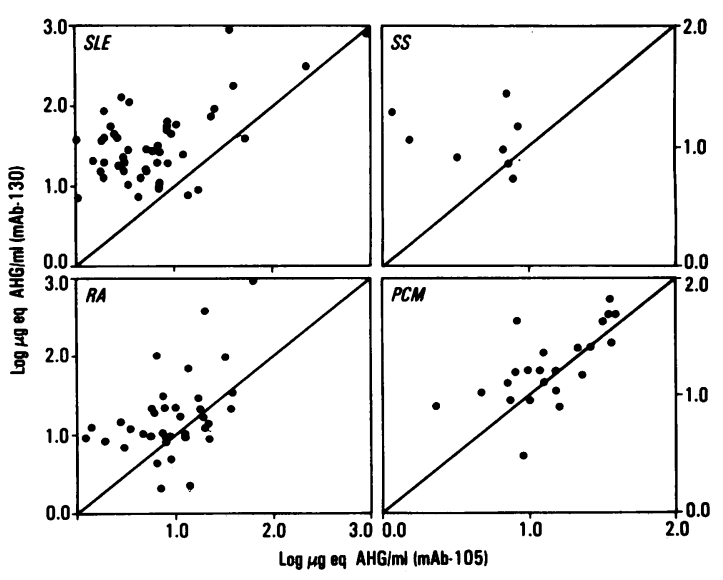

Figure 6. Relationship between $\mathrm{C} 3 \mathrm{~b} / \mathrm{iC} 3 \mathrm{~b}-$ and $\mathrm{iC} 3 \mathrm{~b} / \mathrm{C} 3 \mathrm{~d}-$-containing ICs in patients' plasmas. The former were detected by using $\mathrm{mAb}-105$ (anti-C3c) and the latter by using mAb-130 (anti-C3d). Nanograms of immunoglobulin bound were transformed into $\mu \mathrm{g}$ of eq. AHG $/ \mathrm{ml}$ plasma. 


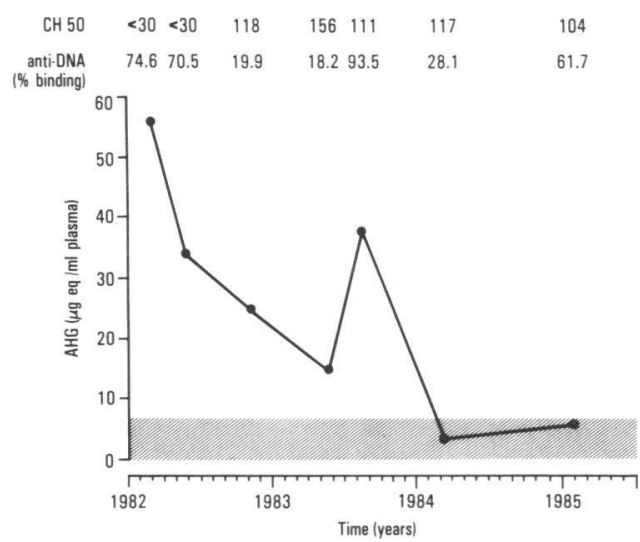

Figure 7. Serial study of an SLE patient, showing the relationship of circulating ICs as detected with mAb-130 with levels of anti-DNA antibodies and total hemolytic complement. The shaded area represents the normal IC range.

frequent divergence of results were observed with $42 \%$ of the samples being positive in one, but not the other assay; $40 \%$ of the samples, however, were positive in both systems.

Correlation between CRI and IC levels and state of $C 3$ on circulating ICs. The number of CR 1 in SLE patients' peripheral erythrocytes is considered lower than normal $(19,25-28)$. Although the number of CR1 is genetically determined (19), it is not known whether this abnormality is genetic in patients with systemic autoimmunity $(19,25,26)$ or secondary to IC-mediated occupation of the CR1 $(26,27)$. The mean \pm 1 SD of CR1 for our SLE patients was $387 \pm 200$ vs. $625 \pm 246$ for normals. Comparison of $\mathrm{CR} 1$ values to levels of $\mathrm{C} 3 \mathrm{~b} / \mathrm{iC} 3 \mathrm{~b}$ or $\mathrm{C} 3 \mathrm{~d}$ ICs revealed no correlation, as assessed with $\mathrm{mAb}-105(r=0.22)$ and $\mathrm{mAb}-$ $130(r=0.12)$, respectively (Fig. 8).

Correlation of IC levels with C3-activation products. Since mAb- 130 binds to a $\mathrm{C} 3$ neoantigen, a system was devised and applied to detect $\mathrm{C} 3$ activation in plasmas, and these results were correlated with IC levels. For detection of $\mathrm{C} 3$ activation products, mAb-130 was bound to microtiter wells and reacted with EDTA-plasmas. Fixed activated C3 was then measured with a radiolabeled (or enzyme-conjugated) polyclonal anti-C3 antibody. As shown in Table III, little C3 bound to wells incubated with normal plasmas or SLE and RA plasmas without ICs. However, significant levels of $\mathrm{C} 3$ activation products correlated with high levels of ICs $(r=0.71 ; P<0.01)$ in SLE or RA patients.

\section{Discussion}

This report demonstrates the usefulness of mAbs that recognize activated C3 neoantigenic determinants to detect and classify ICs, and identify $\mathrm{C} 3$ activation products in human sera.

Activation of the $\mathrm{C}$ system by immunoglobulin aggregates and other substances results in cleavage of native $\mathrm{C} 3$ into $\mathrm{C} 3 \mathrm{a}$ (an anaphylatoxin) and nascent $\mathrm{C} 3 \mathrm{~b}$. This enables the nascent $\mathrm{C} 3 \mathrm{~b}$ to attach covalently to a variety of activation principles via an ester bond formed between a carboxyl group of $\mathrm{C} 3 \mathrm{~b}$ and the activators' surface hydroxyl group. Subsequently, bound C3b interacts with factor $B$ that, under the influence of a serine protease factor $\mathrm{D}$, is cleaved to $\mathrm{Bb}$ and forms a $\mathrm{C} 3 \mathrm{bBb}$ convertase that cleaves $\mathrm{C} 3$ and $\mathrm{C} 5$ molecules (reviewed in reference 29). Under the influence of $\mathrm{CR} 1$ and factor $\mathrm{H}$ acting as co-factors for factor I, particle-bound $\mathrm{C} 3 \mathrm{~b}$ is inactivated to $\mathrm{iC} 3 \mathrm{~b}$, and finally

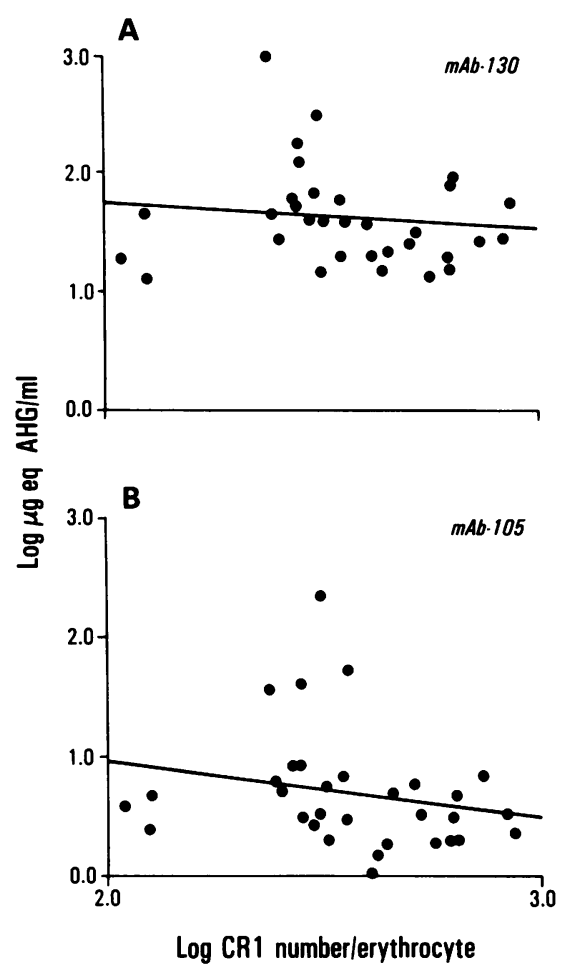

Figure 8. Relationship between the number of $\mathrm{CR} 1 /$ erythrocyte and $\mathrm{C} 3 \mathrm{~b} / \mathrm{iC} 3 \mathrm{~b}$ or $\mathrm{iC} 3 \mathrm{~b} / \mathrm{C} 3 \mathrm{~d}$-containing ICs in SLE patients. CR1 sites were assessed with a polyclonal anti-CR1 antibody. $\mathrm{C} 3 \mathrm{~b} / \mathrm{iC} 3 \mathrm{~b}$ and $\mathrm{iC} 3 \mathrm{~b} /$ C3d-containing ICs were determined with $\mathrm{mAb}-105$ (anti-C3c) and mAb-130 (anti-C3d), respectively. Regression analyses showed no significant correlation between these parameters.

degraded to $\mathrm{C} 3 \mathrm{dg}$ and $\mathrm{C} 3 \mathrm{c}$, with the latter being eluted from the particle (30). In vitro, various enzymes finally split C3dg to C3d and $\mathrm{C} 3 \mathrm{~g}$, but it is debatable whether such breakdown of $\mathrm{C} 3 \mathrm{dg}$ occurs in vivo $(9,23,31)$. Antigenic analysis with polyclonal antisera to $\mathrm{C} 3$ identified distinct antigenic determinants in $\mathrm{C} 3$, C3a, C3c, and C3d (32-34). Further topographic mapping of the $\mathrm{C} 3$ molcule and its fragments with respect to immunochem-

Table III. Relationship between IC Levels and Complement Activation as Detected with mAb-130

\begin{tabular}{ll}
\hline & $\begin{array}{l}\text { ng Anti-C3 } \\
\text { bound } \neq\end{array}$ \\
\hline & mean $\pm 1 S D$ \\
SLE (IC-positive) & $18.22 \pm 9.25$ \\
SLE (IC-negative) & $11.10 \pm 2.32$ \\
RA (IC-positive) & $21.66 \pm 13.33$ \\
RA (IC-negative) & $9.40 \pm 1.73$ \\
Normal plasmas & $9.87 \pm 1.32$ \\
\hline
\end{tabular}

* 10 plasma samples tested in each group.

$\ddagger C$ activation was measured in microtiter wells coated with mAb-130 (anti-C3d neoantigen), subsequently incubated with plasma samples, and finally with radiolabeled polyclonal anti-C3 antibody. The levels of $C$ activation products in plasmas of IC-positive SLE and RA showed a statistically significant increase when compared by the $t$ test to those in normal plasmas $(P<0.02)$. 
ical domains has been achieved by mAbs developed in several laboratories (11-13). Thus, antigenic determinants on the g portion of the molecule $(9,31,35)$ and neoantigenic determinants expressed on activated, but not native, $\mathrm{C} 3(11-13)$ were revealed.

Among the anti-C3 mAbs available to us, two (mAb-105 and $\mathrm{mAb}-130$ ) specifically detected $\mathrm{C}$-fixing ICs, subcategorized ICs according to the $\mathrm{C} 3$ fragment they express, and detected $\mathrm{C} 3$ activation products. mAb-105, developed by Burger et al. (11), reacted primarily with a neoantigenic determinant on $\mathrm{C} 3 \mathrm{c}$, present on particle-bound $\mathrm{C} 3 \mathrm{~b}$ and $\mathrm{iC} 3 \mathrm{~b}$. mAb-130, developed by Tamerius et al. (13), recognized a neoantigenic determinant on $\mathrm{C} 3 \mathrm{~d}$, present also on $\mathrm{iC} 3 \mathrm{~b}$, and bound to its respective epitope whether these fragments were free in fluid phase or on substrates. Our data indicate that the epitope recognized by mAb-105 is inside the folded activated $\mathrm{C} 3$ molcule when free in solution, and is thus inaccessible to the antibody. Conceivably, the binding of activated $\mathrm{C} 3$ to substrates induces a conformational change which results in the generation or exposure of the mAb-105directed epitope. Examples of similar divergence in reactivities of antibodies with the relevant antigens in fluid phase or bound to substrates have also been described by others with certain antibodies against Factor D (36), interleukin 2 (37), and Escherichia coli tryptophan synthase (38).

On the basis of binding characteristics of $\mathrm{mAb}-105$ and $\mathrm{mAb}-$ 130, a modified anti-C3 assay was developed to detect $C$-fixing ICs in biologic fluids. With either mAb, a sensitivity of as little as $6.25 \mu \mathrm{g} \mathrm{AHG} / \mathrm{ml}$ serum was achieved, which is comparable or superior to the most commonly used Raji cell (5) and Clq (3) assays. The reagents used in this highly sensitive assay are available in almost unlimited quantities and, therefore, provide a superior and reproducible substrate for IC detection and appropriate standardization. Since the assay is based on the interaction of $\mathrm{C} 3$ fragments with specific mAbs, it can detect ICs that activate $\mathrm{C}$ via the classical or alternative pathways. This procedure is therefore superior to fluid (3) or solid-phase Clq (39) assays in which only classical C pathway activating ICs can be detected, and to the Raji cell assay in which anti-cellular antibodies, commonly found in autoimmune diseases, may give false positive results (40).

In the initial description of the anti-C3 assay, we used $\mathrm{F}\left(\mathrm{ab}^{\prime}\right)_{2}$ fragments of the polyclonal anti-C3 antibody (6) to avoid false positive results caused by RFs in the test sample. However, a recent report indicated that false positive results can sometimes still be obtained due to the presence of antibodies against $\mathrm{F}\left(\mathrm{ab}^{\prime}\right)_{2}$ (pepsin agglutinators), but not whole IgGs from different species (41). To circumvent this problem, we used whole IgG fractions of the mAbs instead of $F\left(a b^{\prime}\right)_{2}$, and to avoid false results caused by RFs incorporated in the test sample excess aggregated rat or mouse IgG similar to the species from which the mAbs were derived.

Our previous studies have shown that in some IC-positive plasma samples in the polyclonal antibody assay, the anti-C3 bound IgG was sedimenting at the 7-8S position in sucrose gradients (6). Such low molecular weight IgG associated with C3 fragments was primarily found in arthritic and lupus patients whose disease was not associated with systemic IC-mediated manifestations. In contrast, patients with systemic organ involvement (vasculitis and/or glomerulonephritis) had anti-C3 bound IgG at an 11-19S position. This suggested to us IgG dissociation from antigen, but retention of small covalently bound C3 fragments in patients with efficient C-mediated solubilizing activity. In patients with poor $\mathrm{C}$-mediated solubilizing activity, however, most of the IgG remains complexed with antigen and $\mathrm{C}$ fragments. This concept was later challenged by others (20), who remarked that the anti-C3 assay may give false positive results due to $\mathrm{C}$ activation by ICs or other substances and subsequent bystander binding or transfer of activated $\mathrm{C} 3$ from IC to monomeric IgG. Although such a phenomenon might occur, our experiments with a given antigen-antibody system did not reveal significant bystander $\mathrm{C} 3$ binding to monomeric $\mathrm{IgG}$. Therefore, the suggestion that low molecular weight IgG detected by anti-C 3 might be derived from solubilized C-fixing IC remains a likely possibility.

Ross et al. (23) demonstrated that treatment with isotonic serum supplemented with purified CR 1 for $1 \mathrm{~h}$ at $37^{\circ} \mathrm{C}$ cleaved $50 \%$ of activator-bound $\mathrm{C} 3 \mathrm{~b}$ into bound $\mathrm{C} 3 \mathrm{dg}$ and fluid-phase C3c. Our experiments largely confirm this finding, since levels of model ICs incubated with serum plus CR 1 expressing erythrocytes did not register efficiently ( $50 \%$ reduction by $3-4 \mathrm{~h}$ ) when the mAb-105 was the detecting reagent. However, when mAb130 was used, very little effect in accurately registering the actual IC levels was observed over a 24 -h period. Regarding the kinetics of these experiments, it should be noted that some degradation of $\mathrm{C} 3 \mathrm{~b}$ to $\mathrm{iC} 3 \mathrm{~b}$ may have occurred during the preincubation of ICs with serum to allow $C$ fixation before $C R 1$ addition. Furthermore, the amount of ICs used in the experiment can influence the speed of bound $\mathrm{C} 3 \mathrm{~b}$ to $\mathrm{C} 3 \mathrm{dg}$ conversion. However, detection of the ICs using anti-C3d mAb-130 should remain relatively unaltered.

With the mAbs to neoantigens on $\mathrm{C} 3 \mathrm{c}$ and $\mathrm{C} 3 \mathrm{~d}$, increased levels of C-fixing ICs were detected in plasmas of patients with autoimmune diseases (SLE, RA, and SS) and PCM. ICs in sera from similar patients have also been detected by other techniques (2). The nature of the antigen involved in such ICs has not been investigated. Although not extensively studied, a relationship of the IC levels with clinical activity in a patient with SLE is shown in this report. Additional studies correlating IC levels and clinical activity are in progress. It is of interest that, in some patients with all of the above conditions, ICs were detectable by the anti$\mathrm{C} 3 \mathrm{c} \mathrm{mAb}$, which could mean that a relatively large part of the ICs were newly formed and so contained C3b or iC $3 b$. Nevertheless, in most of these conditions the levels recorded by the $\mathrm{mAb}-130$, which recognizes $\mathrm{iC} 3 \mathrm{~b}$ and $\mathrm{C} 3 \mathrm{~d}$, were higher than those with the mAb-105, which recognizes $\mathrm{C} 3 \mathrm{~b}$, iC3b, and $\mathrm{C} 3 \mathrm{c}$, suggesting by this subtractive approach that a larger proportion of the ICs carried the end product ( $\mathrm{dg}$ ) of $\mathrm{C} 3$ degradation. The exception was plasmas of patients with PCM, in whom levels were usually equivalent for both mAbs. This finding suggests either a rapid turnover and continuous formation of new ICs in which the bound $\mathrm{C} 3 \mathrm{~b} / \mathrm{iC} 3 \mathrm{~b}$ is not yet degraded to $\mathrm{C} 3 \mathrm{dg}$, or a considerable defect in the $\mathrm{C} 3 \mathrm{~b} / \mathrm{iC} 3 \mathrm{~b}$ degrading factors, i.e., $\mathrm{CR} 1$, factor $\mathrm{H}$ and factor $\mathrm{I}$, in these patients.

Medof et al. (21) and others $(23,42,43)$ clearly documented the importance of the CR1 in the conversion of $\mathrm{C} 3 \mathrm{~b}$ to $\mathrm{iC} 3 \mathrm{~b}$ and finally to C3dg. Recent studies indicated a diminished number of CR1 receptors on erythrocytes of SLE and RA patients vs. normals $(19,25-27)$. Some investigators believe this defect is genetic $(19,25)$, whereas others indicate that it is acquired and secondary to IC-mediated receptor occupation (27). Our studies on a limited number of SLE patients confirmed lower mean numbers of erythrocyte CR 1 receptors, but failed to discern a significant correlation between IC levels and CR1 numbers, in agreement with others (44), although opposite results have also been published (45). We also found no correlation between 
amounts of ICs detected by the anti-C3c or anti-C3d mAbs and numbers of CR1. One might expect that IC-positive patients with low $\mathrm{CR} 1$ numbers, in which breakdown of $\mathrm{C} 3 \mathrm{~b}$ will be slow, would register equal values with the anti-C3c mAb-105 and anti-C3d mAb-130, since both can recognize their respective epitopes on $\mathrm{C} 3 \mathrm{~b}$ and/or $\mathrm{iC} 3 \mathrm{~b}$. However, since the rate of IC production, $\mathrm{C}$ fixation, and $\mathrm{C}$ degradation are dynamic and asynchronous events, such correlations in a given blood sample may be precluded. Additionally, even so-called "low numbers" of CR1 may be sufficient to convert C3b to iC $3 b$ and C3dg. Future analyses of larger numbers of samples and of serial bleedings over time may permit more definitive conclusions.

The availability of mAbs that recognize C3 neoantigenic determinants has allowed us to develop a simple solid-phase assay system for detecting $\mathrm{C} 3$ activation products. The present system appears to be a considerable improvement over existing procedures, which rely on differential precipitation and mobility characteristics of the $\mathrm{C} 3$ breakdown products vs. native molecule $(46,47)$. This assay identified significant $C 3$ activation in plasmas of patients with a variety of diseases, and correlated $\mathrm{C} 3$ activation products with IC levels, as previously observed by others (47).

To conclude, mAbs to neoantigenic determinants on activated $\mathrm{C} 3$ and its fragments are useful substrates in simple, accurate, and specific assays for IC and $\mathrm{C} 3$ activation product estimation in biologic fluids.

\section{Acknowledgments}

The authors wish to thank Drs. Robert I. Fox, Maura M. Bacchi, Richard S. Smith, and Robert G. Lahita, for providing some of the patient samples used in this study, and Drs. Hans J. Muller-Eberhard and Peter J. Lachmann for providing some of the mAbs. The editorial assistance of Ms. M. K. Occhipinti and Ms. Phyllis Minick is gratefully acknowledged.

This work was supported by National Institutes of Health grants AI07007, AM31023, and AM33826.

\section{References}

1. Theofilopoulos, A. N., and F. J. Dixon. 1980. Detection of immune complexes: techniques and implications. Hosp. Pract. 15:107-121.

2. Theofilopoulos, A. N., and F. J. Dixon. 1979. The biology and detection of immune complexes. Adv. Immunol. 28:89-220.

3. Zubler, R. H., G. Lange, P. H. Lambert, and P. A. Miescher. 1976. Detection of immune complexes in untreated sera by a modified ${ }^{125} \mathrm{I}-$ Clq binding test. J. Immunol. 116:232-235.

4. Eisenberg, R. A., A. N. Theofilopoulos, and F. J. Dixon. 1977. Use of bovine conglutinin for the assay of immune complexes. J. Immunol. 118:1428-1434.

5. Theofilopoulos, A. N., C. B. Wilson, and F. J. Dixon. 1976. The Raji cell radioimmune assay for detecting immune complexes in human sera. J. Clin. Invest. 57:169-182.

6. Pereira, A. B., A. N. Theofilopoulos, and F. J. Dixon. 1980. Detection and partial characterization of circulating immune complexes with solid phase anti-C3. J. Immunol. 125:763-770.

7. Ross, G. 1982. Structure and function of membrane complement receptors. Fed. Proc. 41:3089-3092.

8. Fearon, D. T. 1984. Cellular receptors for fragments of the third component of complement. Immunol. Today (Amst.). 3:105-110.

9. Lachmann, P. J., M. K. Pangburn, and R. G. Oldroyd. 1982. Breakdown of $\mathrm{C} 3$ after complement activation. Identification of a new fragment, C3g, using monoclonal antibodies. J. Exp. Med. 156:205216.

10. Lambris, J. D., J. Alsenz, T. F. Schulz, and M. P. Dierich. 1984. Mapping of the properdin binding site in the third component of complement. Biochem. J. 217:323-326.
11. Burger, R., U. Deubel, U. Hadding, and D. Bitter-Suermann. 1982. Identification of functionally relevant determinants on the complement component C3 with monoclonal antibodies. J. Immunol. 129: 2042-2049.

12. Lachmann, P. J., R. G. Oldroyd, C. Milstein, and B. W. Wright. 1980. Three rat monoclonal antibodies to human C3. Immunology. 41 : 503-515.

13. Tamerius, J. D., M. K. Pangburn, and H. J. Muller-Eberhard. 1982. Selective inhibition of functional sites of cell-bound C3b by hybridoma-derived antibodies. J. Immunol. 128:512-514.

14. Dobson, N. J., J. D. Lambris, and G. D. Ross. 1981. Characteristics of isolated erythrocyte complement receptor type one (CR1, C4bC3b receptor) and CR1-specific antibodies. J. Immunol. 126:693-698.

15. Nisonoff, A., F. C. Wissler, L. N. Lipman, and D. L. Woernley. 1960. Separation of univalent fragments from the bivalent rabbit antibody molecules by reduction of disulfide bonds. Arch. Biochem. Biophys. 89: 230-244.

16. Arend, W. P., D. C. Teller, and M. Mannik. 1972. Molecular composition and sedimentation characteristics of soluble antigen-antibody complexes. Biochemistry. 11:4063-4072.

17. McConahey, P. J., and F. J. Dixon. 1966. A method of trace iodination of proteins for immunologic studies. Int. Arch. Allergy Appl. Immunol. 29:185-189.

18. Salacinski, P. R. P., C. McLean, J. E. C. Sykes, V. V. ClementJones, and P. J. Lowry. 1981. Iodination of proteins, glycoproteins and peptides using a solid-phase oxidizing agent, 1,3,4,6-tetrachloro3alpha,6alpha-diphenyl glycoluril (Iodogen). Anal. Biochem. 117:136146.

19. Wilson, J. G., W. W. Wong, P. M. Schur, and D. T. Fearon. 1982. Mode of inheritance of decreased C3b receptors on erythrocytes of patients with systemic lupus erythematosus. New Eng. J. Med. 307: 981-986.

20. Jacobs, R. J., and M. Reichlin. 1983. Generation of low M.W., C3-bearing immunoglobulin in human serum. J. Immunol. 130:27752781.

21. Medof, M. E., K. Iida, C. Mold, and V. Nussenzweig. 1982. Unique role of the complement receptor CR1 in the degradation of $\mathrm{C} 3 \mathrm{~b}$ associated with immune complexes. J. Exp. Med. 156:1739-1754.

22. Medof, M. E., G. M. Prince, and C. Mold. 1982. Release of soluble immune complexes from immune adherence receptors on human erythrocytes is mediated by $\mathrm{C} 3 \mathrm{~b}$ inactivator independently of beta $1 \mathrm{H}$ and is accompanied by generation of C3c. Proc. Natl. Acad. Sci. USA. 79:5047-5051.

23. Ross, G. D., J. D. Lambris, J. A. Cain, and S. L. Newman. 1982. Generation of three different fragments of bound $\mathrm{C} 3$ with purified Factor I or serum. I. Requirements for Factor $\mathrm{H}_{\text {vs. }} \mathrm{CR}_{1}$. J. Immunol. 129: 2051-2060.

24. Law, S. K., N. A. Lichtenberg, and R. P. Levine. 1979. Evidence for an ester linkage between the labile binding site of $\mathrm{C} 3 \mathrm{~b}$ and receptive surfaces. J. Immunol. 123:1388-1394.

25. Miyakawa, Y., A. Yamada, K. Kosaka, F. Tsuda, E. Kosugi, and M. Mayumi. 1981. Defective immune adherence (C3b) receptor on erythrocytes from patients with systemic lupus erythematosus. Lancet. II:493-497.

26. lida, K., R. Mornaghi, and V. Nussenzweig. 1982. Complement receptor (CR1) deficiency in erythrocytes from patients with systemic lupus erythematosus. J. Exp. Med. 155:1427-1438.

27. Ross, G. D., M. J. Walport, C. J. Parker, A. F. Lentive, C. R. Fuller, W. J. Yount, B. L. Myones, J. B. Winfield, and P. J. Lachmann. 1984. Acquired loss of erythrocyte (E) $C_{1}$ (C3b-receptor) in systemic lupus erythematosus (SLE) and other diseases with autoantibodies and/ or complement (C) activation. Arthritis Rheum. 27(Suppl.):528. (Abstr.)

28. Dykman, T. R., J. A. Hatch, and J. P. Atkinson. 1984. Polymorphism of the human $\mathrm{C} 3 \mathrm{~b} / \mathrm{C} 4 \mathrm{~b}$ receptor. Identification of a third allele and analysis of receptor phenotypes in families and patients with systemic lupus erythematosus. J. Exp. Med. 159:691-703.

29. Pangburn, M. K. 1983. Activation of complement via the alternative pathway. Fed. Proc. 42:139-143. 
30. Fearon, D. T., and W. W. Wong. 1983. Complement ligandreceptor interactions that mediate biological responses. Annu. Rev. Immunol. 1:243-271.

31. Lachmann, P. J., D. Voak, R. G. Oldroyd, D. M. Downie, and P. C. Bevan. 1983. Use of monoclonal anti-C3 antibodies to characterise the fragments of $\mathrm{C} 3$ that are found on erythrocytes. Vox Sang. 45:367372.

32. Hansen, O., J. C. Jensenius, J. Folkersen, and I. Brandslund. 1983. Production of antibody against $\mathrm{C} 3 \mathrm{c}$ epitopes which are inaccessible on native C3. J. Immunol. Methods. 61:245-252.

33. West, C. D., N. C. Davis, J. Forristal, J. Herbst, and R. Spitzer. 1966. Antigenic determinants of human beta $1 \mathrm{C}$ and beta $1 \mathrm{G}$ globulins. J. Immunol. 96:650-658.

34. Molenaar, J. L., A. T. Velde, and K. W. Pondman. 1973. AntiC3a, anti-C3b (anti-B) and their reaction with anaphylactic fragment C3a. J. Immunol. 110:702-708.

35. Chaplin, H., M. C. Monroe, and P. J. Lachmann. 1982. Further studies of the C3g component of the alpha 2D fragment of human C3. Clin. Exp. Immunol. 51:639-646.

36. Niemann, M. A., J. F. Kearney, and J. E. Volanakis. 1984. The use of monoclonal antibodies as probes of the three-dimensional structure of human complement factor D. J. Immunol. 132:809-815.

37. Altman, A., J. M. Cardenas, R. A. Houghten, F. J. Dixon, and A. N. Theofilopoulos. 1984. Antibodies of predetermined specificity against chemically-synthesized peptides of human interleukin 2. Proc. Natl. Acad. Sci. USA. 81:2176-2180.

38. Friguet, B., L. Djavadi-Ohaniance, and M. E. Goldberg. 1984. Some monoclonal antibodies raised with a native protein bind preferentially to the denatured antigen. Mol. Immunol. 21:673-677.

39. Hay, F. C., L. J. Nineham, and I. M. Roitt. 1976. Routine assay for detection of immune complexes of known immunoglobulin class using solid-phase Clq. Clin. Exp. Immunol. 24:396-400.
40. Anderson, C. L., and W. S. Stillman. 1980. Raji cell assay for immune complexes: evidence for detection of Raji-directed immunoglobulin $\mathbf{G}$ antibody in sera from patients with systemic lupus erythematosus. J. Clin. Invest. 66:353-360.

41. Olds, L. C., and J. J. Miller. 1984. Anti-F( $\left(\mathrm{ab}^{\prime}\right)_{2}$ antibodies that interfere with interpretation of the anti-C3 assay for immune complexes in children with rheumatic diseases. Arthritis Rheum. 27:330-336.

42. Iida, K., and V. Nussenzweig. 1981. Complement receptor is an inhibitor of the complement cascade. J. Exp. Med. 153:1138-1150.

43. Fearon, D. T. 1979. Regulation of the amplification C3 convertase of human complement by an inhibitory protein isolated from human erythrocyte membrane. Proc. Natl. Acad. Sci. USA. 76:5867-5871.

44. Wilson, J. G., D. T. Fearon, and P. H. Schur. 1984. Correlation between erythrocyte (E) $\mathrm{C} 3 \mathrm{~b}$ receptor (C3bR) number and antibody to double-stranded DNA (anti-dsDNA) in systemic lupus erythematosus (SLE). Arthritis Rheum. 27(Suppl.):S82.

45. Inada, Y., M. Kamiyama, T. Kanemitsu, C. L. Hyman, and W. S. Clark. 1982. Studies on immune adherence (C3b) receptor activity of human erythrocytes: relationship between receptor activity and presence of immune complexes in serum. Clin. Exp. Immunol. 50:189-197.

46. Perrin, L. H., P. H. Lambert, and P. A. Miescher. 1975. Complement breakdown products in plasma from patients with systemic lupus erythematosus and patients with membranoproliferative or other glomerulonephritis. J. Clin. Invest. 56:165-176.

47. Berkowicz, A., J. Rosenkvist, and H. Sorensen. 1983. A single step immunoelectrophoresis method for the quantitation of complement C3c in biological fluids. J. Immunol. Methods. 60:277-288.

48. Nydegger, U. E., R. H. Zubler, R. Gabay, G. Joliat, C. Karagevrekis, P. H. Lambert, and P. A. Miescher. 1977. Circulating complement breakdown products in patients with rheumatoid arthritis. J. Clin. Invest. 59:862-868 